\title{
Critical care nursing education in the Philippines
}

Maria Isabelita C Rogado, RN; MA Nursing, Head, Division of Nursing Education, Philippine Heart Center, the Philippines.

E-mail: bellerogado@yahoo.com

Key words: Accreditation critical care nursing education history the Philippines

\section{SUMMARY}

* Nurses make up the biggest number of healthcare professionals in the Philippines, but there are very few nursing jobs available for Filipino nurses.

* The majority of the nursing population seek job opportunities overseas.

* Nurses are educated on a four-year programme of competency-based and community-orientated units leading to a Bachelor of Science in Nursing award.

* The accreditation of nurses is slow as nurses and organisations strive to meet government targets. This is compounded by professionals moving abroad to work.

* Working abroad, however, provides a boost to the nurses' own and their families' financial and economic state as well as that of the country as a whole.

* Critical care nursing in the Philippines is described within the above context.

\section{BACKGROUND}

\section{The Philippines}

The Philippines is a tropical country which lies in the heart of South East Asia, surrounded by the Pacific Ocean. It consists of 7,107 islands with three major island groupings: Luzon in the north, Mindanao in the south, and Visayas in between. The country's business and government centre is Metro Manila, located in the National Capital region in Luzon.

The Philippines stands at the crossroads of the developed western world and the Orient. Its unique location has made the Philippines the commercial, cultural and intellectual hub of Asia. Its geography also makes it prone to national disasters like typhoons, floods, earthquakes and volcanic eruptions. It is a country with a colourful culture and diverse customs and traditions, shaped by Chinese, Spanish and American influences. The estimated population in 2004 was 84 million, with a literacy rate of $83.8 \%$. The Philippines is the third largest English-speaking country in the world.

\section{Overview of the health care system of the Philippines}

Among the registered health professionals, nurses account for the biggest number. Table 1 shows the number of health professionals registered in the Philippines between 1991-2000 and Table 2 gives a break down of the number of nurses who qualified during this period (Professional Regulation Commission, 2005). However, there are very few nursing positions or nursing jobs available for Filipino nurses. The Philippines can only provide jobs for $15-25 \%$ of the nursing population and the remaining $75-85 \%$ pursues professional job opportunities overseas. The government has an estimated 18,000 nursing positions with a turnover of 1,000 jobs per year.

The growing exodus or migration of Filipino nurses has stimulated the curiosity of other countries to know more about Philippine nursing and what makes Filipino nurses exportable.

\begin{tabular}{|l|l|}
\hline Profession & Total registrations \\
& $\mathbf{1 9 9 1 - 2 0 0 0}$ \\
\hline Dentist & 41,484 \\
Dental hygienist & 6 \\
Medical technology & 40,879 \\
Medical laboratory technician & 3,323 \\
Physician & 95,016 \\
Midwife & 129,532 \\
Nurse & 337,939 \\
Nutritionist dietician & 10,841 \\
Dietician & 1,410 \\
Optometrist & 9,155 \\
Pharmacist & 44,316 \\
Chinese druggist & 485 \\
Physical \& occupational therapist & 11,442 \\
Physical therapist & 1,191 \\
Occupational therapist & 78 \\
Physical therapy technician & 119 \\
Occupational therapy technician & 4,034 \\
Radiology technologist & 8,031 \\
\hline
\end{tabular}

Table 1. Registered health professionals 1991-2000 (Professional Regulation Commission, 2005)

\begin{tabular}{|lllllll|}
\hline $\mathbf{2 0 0 0}$ & $\mathbf{1 9 9 9}$ & $\mathbf{1 9 9 8}$ & $\mathbf{1 9 9 7}$ & $\mathbf{1 9 9 6}$ & $\mathbf{1 9 9 5}$ & $\mathbf{1 9 9 4}$ \\
\hline 337,939 & 5,784 & 8,419 & 9,441 & 11,693 & 15,701 & 27,272 \\
\hline $\mathbf{1 9 9 3}$ & $\mathbf{1 9 9 2}$ & $\mathbf{1 9 9 1}$ & $\mathbf{2 0 0 0}$ & & & \\
\hline 29,445 & 30,921 & 15,986 & 9,165 & & & \\
\hline
\end{tabular}

Table 2. Registered Nurses 1991-2000 (Professional Regulation Commission, 2005) 


\section{Philippine nursing education}

The Philippines is the only country among the Asia-Pacific Economic Cooperation (APEC) member countries that has one basic preparation for nursing practice - a Bachelor degree programme (Barcelo and Bustamante, 1998). Nurses are educated through a combination of competency-based and community-oriented Bachelor of Science in Nursing (BSN) courses. The Philippine curriculum has several advantages compared with curricula in other APEC institutions (Ramirez, 2001). This kind of education offers much more than a solely skills-based curriculum can. The four-year requirement to earn a Bachelor degree in nursing meets the minimum entry requirement for professional nursing practice.

The first two years of general education is grounded on liberal arts that strengthen the values and character of a person as a care-giver, which is a clear advantage over the purely skilled worker. The language of instruction in all local institutions is English, which prepares the student for licensure examinations both locally and internationally. This also gives the nurses access to the ever-growing literature in health sciences. The communication skills, competency and confidence in the use of the English language certainly contribute to effective healthcare in any setting. The curriculum also strengthens the capabilities of the students to participate in research in nursing and other health sciences, provides flexibility in, and openness to, the use of new teaching approaches, and encourages active involvement in extension work that reaches out to other sectors (Barcelo, 2001).

\section{Bachelor of Science in Nursing (BSN) curriculum}

The innovative BSN curriculum of 1984 is the only nursing programme in the Philippines and has gained recognition among the nursing communities around the world. This four-year competency-based curriculum comprises two years of general education and associate health science education. The remaining two years are focused on nursing education and related learning experience.) A summary of the curriculum can be seen in Tables 3 and 4 .

\begin{tabular}{|c|c|c|c|}
\hline \multirow[t]{4}{*}{ General Education } & Language and Humanities & $\begin{array}{l}\text { English Communication I \& II } \\
\text { Filipino I \& II } \\
\text { Introduction to Literature } \\
\text { English III } \\
\text { Philosophy of Man } \\
\text { Logic and Critical Thinking }\end{array}$ & $\begin{array}{l}6 \text { units } \\
6 \text { units } \\
3 \text { units } \\
3 \text { units } \\
3 \text { units } \\
3 \text { units }\end{array}$ \\
\hline & $\begin{array}{l}\text { Mathematics, Natural Sciences } \\
\text { and Information Technology }\end{array}$ & $\begin{array}{l}\text { Mathematics } \\
\text { Chemistry } \\
\text { Bio/Geo/Earth Sciences } \\
\text { Physics } \\
\text { Anatomy/Physiology } \\
\text { Microbiology \& Parasitology } \\
\text { Information Technology }\end{array}$ & $\begin{array}{l}3 \text { units } \\
5 \text { units } \\
3 \text { units } \\
3 \text { units } \\
5 \text { units } \\
4 \text { units } \\
3 \text { units }\end{array}$ \\
\hline & Social Sciences & $\begin{array}{l}\text { Psychology } \\
\text { Sociology/Anthropology } \\
\text { Philippine History } \\
\text { Philippine Government and Constitution } \\
\text { Asian Civilisation }\end{array}$ & $\begin{array}{l}3 \text { units } \\
3 \text { units } \\
3 \text { units } \\
3 \text { units } \\
3 \text { units }\end{array}$ \\
\hline & $\begin{array}{l}\text { Associate in Health Science } \\
\text { and Education }\end{array}$ & $\begin{array}{l}\text { Primary Health Care I with Related } \\
\text { Learning Experience } \\
\text { Primary Health Care II with Related } \\
\text { Learning Experience } \\
\text { Health Economics, Taxation and Land } \\
\text { Reform } \\
\text { Bioethics } \\
\text { Basic Nutrition } \\
\text { Science, Technology and Society }\end{array}$ & $\begin{array}{l}7 \text { units } \\
5 \text { units } \\
3 \text { units } \\
3 \text { units } \\
3 \text { units } \\
3 \text { units }\end{array}$ \\
\hline
\end{tabular}

Table 3. General education (first two years of BSN curriculum) 


\begin{tabular}{|c|c|c|}
\hline Nursing Education & $\begin{array}{l}\text { *NCM } 100 \text { - Foundation of Nursing Practice } \\
\text { NCM } 101 \text { - Promotion and Preventive Nursing Care Management } \\
\text { NCM } 102 \text { - Curative and Rehabilitative Nursing Care Management I } \\
\text { NCM } 103 \text { - Related Learning Experience } \\
\text { NCM } 104 \text { - Curative and Rehabilitative Nursing Care Management II } \\
\text { NCM } 105 \text { - Nursing Management / Leadership } \\
\text { Introduction to Nursing research } \\
\text { Strategies to Health Education } \\
\text { Community Health Development }\end{array}$ & $\begin{array}{l}3 \text { units } \\
16 \text { units } \\
16 \text { units } \\
4 \text { units } \\
16 \text { units } \\
16 \text { units } \\
3 \text { units } \\
3 \text { units } \\
3 \text { units }\end{array}$ \\
\hline $\begin{array}{l}\text { Related Nursing Experience } \\
\text { (RLE) }\end{array}$ & $\begin{array}{l}\text { **PHC I (153 hours) } \\
\text { PHC II (102 hours) } \\
\text { NCM } 100 \text { (51 hours) } \\
\text { NCM } 101 \text { (408 hours) } \\
\text { NCM } 102 \text { (408 hours) } \\
\text { NCM } 103 \text { (204 hours) } \\
\text { NCM } 104 \text { (408 hours) }\end{array}$ & $\begin{array}{l}3 \text { units } \\
2 \text { units } \\
1 \text { units } \\
8 \text { units } \\
8 \text { units } \\
4 \text { units } \\
8 \text { units }\end{array}$ \\
\hline
\end{tabular}

Table 4. Nursing education and related learning experiences (final two years of BSN curriculum)

*NCM (Nursing Care Management), **PHC (Primary Health Care)

\section{Nursing licensure}

The nurse must pass the national licensure written examination administered by the Professional Regulation Commission Board of Nursing to qualify for registration. A certificate of registration/ professional licence as a nurse is issued to those who pass the examination. The licence to practice is renewed every three years on the nurse's birthday.

\section{Reciprocity}

In Section 19 of the Philippine Nursing Act (2002) it states that a certificate of registration/professional licence may be issued without examination to nurses registered under the laws of a foreign state or country. However, the requirements for registration or licensing must be substantially the same as those prescribed under this Act, and the foreign state or country's laws must grant the same privileges to registered nurses of the Philippines as its own citizens.

\section{Philippine nursing law}

Philippine nursing practice is governed by the Philippine Nursing Act (2002), also known as the Republic Act No. 9173, which was passed by the House of Representatives and the Senate on 15 October 2002.

The Nursing Act emphasises the expansion of the nurse's role to include comprehensive speciality programmes. Section 31 states that the Board of Nursing, in co-ordination with the accredited professional organisation, recognised speciality organisations and the Department of Health, must formulate and develop a comprehensive nursing speciality programme to upgrade the level of skill and competency of speciality nurse clinicians in the country. Such specialities include critical care, oncology, renal and other such areas as specified by the Board of Nursing. The beneficiaries of this programme are obliged to serve in any Philippine hospital for a period of at least two years' continuous service.

The Nursing Act establishes a minimum base pay for nurses working in government. Section 32 states that, to enhance the general welfare, commitment to service and professionalism of nurses, the minimum base pay of nurses working in public health institutions should not be lower than salary grade 15 prescribed under Republic Act No. 6758, known as the Compensation and Classification Act 1989

\section{SPECIALITY NURSING IN THE PHILIPPINES}

Nursing leaders in the Philippines started talking seriously about nursing specialisation in 1996. The discussion was led by the Professional Regulation Commission Board of Nursing. It created a core group with the task of developing a position paper for the accreditation programme in the Philippines. This project came as part of a commitment to the APEC/General Agreement on Tariffs and Trade (GATT) agreement whereby the Philippines started to liberalise professional services, expecting health professionals to provide high quality care to health care consumers.

The Core Committee headed by Deogracia Valderrama started its work and, by 1998, the framework for accreditation was submitted for approval. The framework was based on Benner's (1984) conceptual framework which adopted five stages of skill acquisition in clinical practice. This became the infrastructure of the programme, based on Benner's development philosophy that nurses move from novice to expert clinicians through a series of simple to complex experiences.

After consultation with the Commissioners of the Professional Regulation Commission (PRC) and members of the Board of Nursing, the recommendation and proposal of the Core Committee was approved as Resolution 99-14 on 19 February 1999 (PRC, 1999; 2002). The framework for accreditation is seen in Table 5.

At present, the national speciality organisations in the Philippines and the nurses pursuing specialisation are striving to meet these 


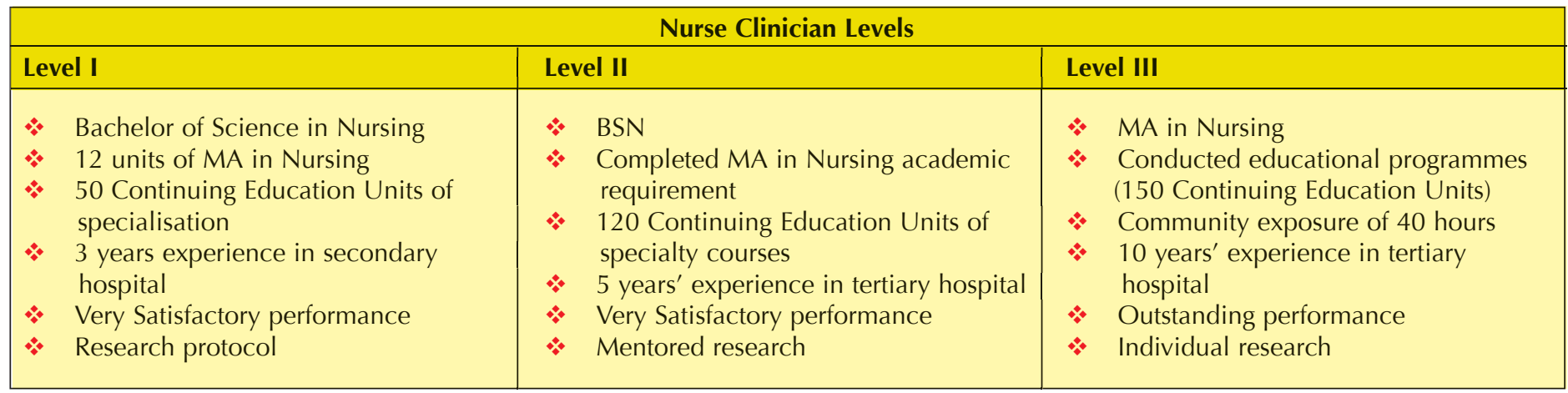

Table 5. Framework for accreditation

requirements. The pace is slow. Currently there are only seven accredited speciality organisations and 52 nurses with nurse clinician credentials at various levels. The accreditation mechanism needs to be used and valued in the Philippines by nurses and their healthcare partners. One setback in the process is that no commensurate professional fee or recompense is currently given to those who are accredited. This issue will take more initiative and effort from the national nursing organisations and nurses to lobby for the corresponding financial recognition that accredited nursing professionals deserve.

Migration of Filipino nurses is also a factor that affects the pace of accreditation in the Philippines. Nurses who have gained two years or more of experience are lured to leave the country and work overseas where they fulfil their professional advancement.

\section{CRITICAL CARE NURSING IN THE PHILIPPINES}

In 1970, the health care system in the Philippines was greatly affected by advancements in care and technology and the changing nature of care. These factors influenced the development of speciality practice, particularly in critical care.

Critical care practice is a collaborative process and nurses play a vital part in it. Critical care nurses assume the role of direct caregivers to the patient. They are expected to possess the competency necessary to work in complex critical care areas or the intensive care unit (ICU) environment. To be able to meet the demands of this type of care, recruitment of nurses must be based on skill levels. The patient to nurse ratio in the ICU of most Metro Manila tertiary hospitals is usually $1: 2$. However, this is not a consistent picture in other government or private hospitals throughout the country.

Most critical care nurses in the Philippines have not been educationally prepared for critical care practice. They have developed knowledge and skills 'on the job' through mentoring or preceptoring by senior nurses. There is no difference in salary between critical care nurses and 'ordinary' ward nurses, and newly hired nurses can be deployed immediately in any ICU setting to augment staffing. However, with the specialisation programme as required by the Nursing Act 2002, most hospitals are trying to comply with the guidelines for hospital accreditation to have nurses trained and educated in critical care nursing practice.

Critical care programmes are provided by only a few tertiary hospitals in Metro Manila. These programmes are not currently reviewed or accredited by the national Critical Care Nurses Association of the Philippines. However, development of a mechanism for accreditation of speciality programmes is being discussed by the Professional Regulation Commission Board of Nursing and speciality nursing organisations. This mechanism will still have to be approved before it can be made a requirement for critical care practice.

\section{The cost of training}

There is a dilemma faced by hospitals in bearing the cost of training nurses in speciality areas. This is related to the fast turnover and mobility of nurses. After having been trained, nurses often seek employment in local hospitals that pay higher salaries or migrate to hospitals abroad. Despite the efforts of sponsoring hospitals to establish a working contract, the nurses usually resign once they are accepted at a better-paying hospital and just pay the corresponding cost of the training programme. This leaves the levels of qualified nurses in the country in a poor state.

The Philippine Heart Center, a nationally recognised training institution for critical care and cardiovascular specialisation, initiated a career path for nurses which served as a model for other institutions. Their training strategy is also a retention programme that makes nurses commit to stay for a minimum of two years. Structured training (as shown in Figure 1) is provided for nurses to prepare them for the next level of competency. Their pay is adjusted accordingly, based on gaining at least the minimum qualification at each level.

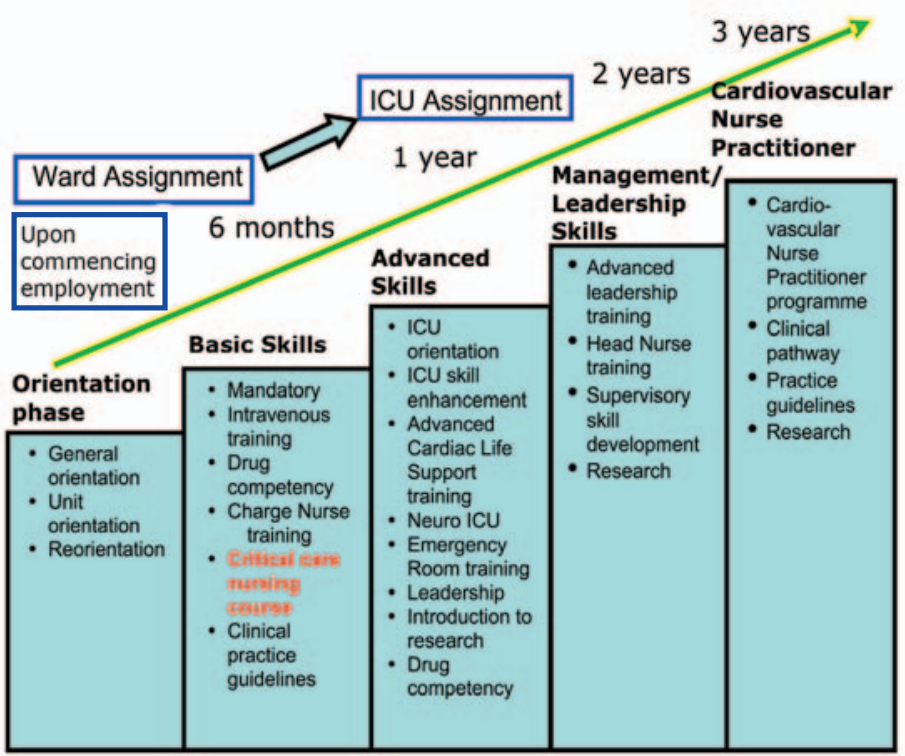

Figure 1. Structured career ladder: framework for specialisation at the Philippine Heart Center 


\section{CONCLUSIONS}

At this time in the Philippines there are many issues that confront nursing leaders. The biggest issue is the migration of Filipino nurses. However, for many Filipino nurses, working abroad is a welcome opportunity that will uplift the financial and economic state of their own families and the country as well. With the exodus of nurses, the Philippines has a significant shortage of qualified nurses with whom to meet the country's own health care needs. Efforts are already being exhausted to augment the compromised state of health care delivery. Despite the attempts of many nursing leaders in the Philippines to improve nursing education and nursing practice, the reality of meeting the needs of 84 million Filipino people poses an outstanding challenge.

\section{REFERENCES}

Barcelo TI (2001) Internationalization of Nursing Education. Philippine Journal of Nursing 71 (3-4), 15-19.

Barcelo TI, Bustamante I (1998) Nursing in APEC Member\Countries,
Department of Research, Philippine Nurses Association. Benner, P (1984). From Novice to Expert: Excellence and Power in Clinical Nursing Practice. Menlo Park, California, Addison-Wesley.

Philippine Nursing Act (2002). Republic Act No. 9173. Philippine Journal of Nursing 72 (2), 21-32.

Professional Regulation Commission (1999) Nursing Speciality Certification Program. Board of Nursing Resolution No. $14 \mathrm{~s}$.

Professional Regulation Commission (2002) Nursing Speciality Certification

Program. Guidelines for Implementation of Board of Nursing Resolution No. 118- S.

Professional Regulation Commission (2005). Health Statistics [online]. Available at: http://www.doh.gov.ph/data_stat/html/health_professional. htm Accessed July 2005.

Ramirez, V (2001) Philippine maritime and nursing education benchmarking with APEC best practices. Conference paper presented at the 2nd National Conference on Management of International Education and Linkages, The Philippines, 06 December 2001. 